\section{Analisis Hukum Atas Perjanjian Kerjasama Pengelolaan Persampahan Antara Pemerintah Provinsi Sumatera Utara Dengan Pemerintah Kota Medan Berdasarkan Peraturan Daerah Nomor 6 Tahun 2015 Tentang Pengelolaan Persampahan (Studi Dinas Kebersihan Kota Medan)}

Oleh :

\author{
Ervina Sari Sipahutar ${ }^{1}$ \\ Email : vina.sofyan@gmail.com
}

\begin{abstract}
Abstrak
Di Indonesia masalah sampah merupakan masalah yang sangat rumit, dalam masyarakat yang kurang memiliki kepekaan terhadap lingkungan. Ketidak disiplinan mengenai kebersihan dapat menciptakan suasana yang tidak baik akibat timbunan sampah. Perkembangan kota secara tidak langsung disebabkan oleh pertambahan jumlah penduduk kota. dalam hal ini pengelolaan sampah, kota Medan memiliki peraturan khusus dalam pengelolaan sampah yaitu diatur dalam Peraturan Daerah Nomor 6 Tahun 2015 tentang Pengelolaan Persampahan. Berdasarkan Pasal 1 Peraturan Daerah Nomor 6 Tahun 2015 tentang Pengelolaan Persampahan. untuk itu, pemerintah kota Medan dan pemerintah provinsi Sumatera Utara membuat perjanjian mengenai pengelolahan sampah tersebut. Mengenai bentuk dan isi perjanjian diserahkan kepada kesepakatan pihak yang melakukan perjanjian tersebut.
\end{abstract}

Kata Kunci : Perjanjian Kerjasama, Pengelolaan Sampah, Pemerintah Provinsi Sumatera Utara, Pemerintah Kota Medan

\footnotetext{
${ }^{1}$ Dosen Fakultas Hukum Al-Azhar Medan
}

\begin{abstract}
The problem of waste in Indonesia is a very complex problem in a society that lacks sensitivity to the environment. Undisciplined cleanliness can create a bad atmosphere due to piles of garbage. The city development is indirectly caused by the increase in the population of the city. In this case, waste management in Medan city has a special regulation in waste management which is regulated in Regional Regulation Number 6 of 2015 concerning Solid Waste Management. It is based on Article 1 of Regional Regulation Number 6 of 2015 concerning Solid Waste Management. Therefore, Medan city government and North Sumatra provincial government made an agreement regarding the management of this waste. Regarding the form and the content of the agreement, it is submitted to the agreement of the parties conducting the agreement.
\end{abstract}

Keywords : Cooperation Agreement, Waste Management, North Sumatra Provincial Government, Medan City Government

\section{PENDAHULUAN}

Permasalahan sampah diperkotaan adalah salah satu masalah yang masih menjadi tantangan besar bagi pengelolah kota untuk ditangani. Pertambahan jumlah penduduk dari tahun ke tahun telah mengakibatkan meningkatnya aktivitas yang tentu saja juga berimplikasi terhadap peningkatan produksi sampah diperkotaan. Pengelolaan di kota - kota besar sampai saat ini belum dapat diperoleh hasil yang optimal. Berbagai kendala yang dihadapi dalam melaksanakan pengelolaan sampah tersebut baik kendala ekonomi, sosial budaya maupun lingkungan. sementara itu sebagian besar masyarakat kota juga masih belum terbiasa dengan sistem pengelolaan sampah yang baik, pada hal peran serta masyarakat juga sangat penting dalam sistem 
Media Komunikasi dan Informasi Hukum dan Masyarakat

pengelolaan sampah. Sehingga dibutuhkan kesadaran dan komitmen bersama menuju perubahan sikap, perilaku dan etika yang berbudaya lingkungan. Sebagian upaya menggugah kepedulian dalam penanganan permasalahan lingkungan, khususnya persampahan serta untuk menciptakan kualitas lingkungan yang bersih dan ramah lingkungan, maka harus dilakukan perubahan paradigma pengelolaan sampah dengan cara: (1) Pengurangan volume sampah dari sumbernya dengan pemilihan, atau pemprosesan dengan teknologi yang sederhana seperti composting dengan skala rumah tangga atau skala lingkungan. (2) Peran serta masyarakat dalam pengelolaan sampah dikoordinir oleh Kelompok Swadaya Masyarakat (KSM) kelompok ini bertugas mengkoordinir kebersihan lingkungan.

Dampak yang di timbulkan apabila sampah tidak ditangani dengan baik maka akan tampak pada 3 aspek yaitu: Pertama, aspek kesehatan yaitu sampah dapat memberikan tempat tinggal bagi vektor penyakit tikus, cacing, jamur dan lain - lain. Kedua, aspek lingkungan yaitu sampah dapat mengganggu estetika (keindahan) dan kenyamanan yang merupakan gangguan bagi pandangan mata dengan adanya sampah yang berserakan dan kotor, atau tumpukan sampah yang terbengkelai adalah pemandangan yang tidak disukai oleh sebagian besar masyarakat.

Peningkatan penduduk di daerah perkotaan juga mengakibatkan perubahan lahan untuk mengimbangi. Namun perubahan yang tidak terkendali akan mengakibatkan dampak negatif bagi perkembangan kota dan lingkungan kota. Banyaknya lahan terbangun menyebabkan lahan kosong semakin lama semakin sedikit. Perkembangan kota menuntut daya dukung yang memadai.
Dewasa ini, kota Medan sedang melaksanakan pembangunan di segala bidang dalam rangka memajukan kesejahteraan, meningkatkan taraf hidup masyarakat kota Medan. $\mathrm{Di}$ pihak lain, muncul pula permasalahan - permasalahan yang merupakan timbal balik dari proses pelaksanaan pembangunan. Dari sekian banyak permasalahan yang terjadi tersebut salah satunya adalah masalah lingkungan yang perlu mendapat penanganan serius dari pemerintah kota Medan.

Hal ini untuk menunjang kelangsungan pembangunan seperti yang tertuang dalam Pasal 1 angka (3) Undang - Undang Pengelolaan Lingkungan Hidup Nomor 23 Tahun 1997, yang menyatakan, "Bahwa pembangunan berkelanjutan yang berwawasan lingkungan hidup adalah upaya sadar dan terencana yang memadukan lingkungan hidup, termasuk sumber daya ke dalam proses pembangunan untuk menjamin kemampuan, kesejahteraan dan mutu hidup generasi masa kini dan generasi masa depan".

Sejalan dengan uraian di atas, permasalahan sampah merupakan salah satu permasalahan yang terkait langsung dengan lingkungan hidup. Berdasarkan Undang Undang No 18 Tahun 2008 tentang Pengelolaan Sampah bahwa "Sampah adalah sisa kegiatan sehari - hari manusia dan/atau proses alam yang berbentuk padat". Sampah merupakan masalah yang harus dihadapi oleh masyarakat, karena sampah merupakan salah satu wujud pencemaran lingkungan, dimana karena aktivitas manusia (faktor eksternal) menyebabkan zat asing yang pada mulanya tidak ada dalam kawasan lingkungan hidup masuk kedalam lingkungan tersebut. dalam Peraturan Daerah Nomor 6 Tahun 2015 tentang 
Media Komunikasi dan Informasi Hukum dan Masyarakat

Pengelolaan Persampahan. Berdasarkan Pasal

1 Peraturan Daerah Nomor 6 Tahun 2015 tentang Pengelolaan Persampahan, bahwa : Pengelolaan persampahan adalah kegiatan yang sistematis, menyeluruh dan berkesinambungan yang meliputi pengurangan dan penanganan sampah. Sampah sudah menjadi masalah bagi pelestarian lingkungan. Maka dari itu sudah menjadi tanggung jawab pemerintah daerah kota Medan dan kesadaran masyarakat untuk melestarikan lingkungan serta diperlukannya upaya pemecahan masalah sampah.

Untuk itu, pemerintah kota Medan dan pemerintah provinsi Sumatera Utara membuat perjanjian mengenai pengelolahan sampah tersebut. Mengenai bentuk dan isi perjanjian diserahkan kepada kesepakatan pihak yang melakukan perjanjian tersebut. Ini sesuai dengan ketentuan mengenai perikatan dalam Kitab Undang - Undang Hukum Perdata (KUHPerdata), khususnya dalam Buku III KUHPerdata yang mempunyai sifat terbuka dan adanya asas kebebasan berkontrak. Perjanjian telah diatur dalam Pasal 1313 KUHPerdata, bahwa : "Suatu persetujuan adalah suatu perbuatan di mana satu orang atau lebih mengikatkan diri terhadap satu orang lain atau lebih".

Kewajiban pihak kedua adalah : 1) Menjamin kebersihan, keamanan dan ketertiban (K3) terhadap pengiriman sampah dari Kabupaten/Kota sampai ke lokasi TPA Sampah Regional; 2) Menyediakan anggaran sebagai jasa pemrosesan sampah di TPA Sampah Regional yang akan ditetapkan berdasarkan kesepakatan para pihak dengan mempertimbangkan prinsip pemulihan biaya dan pelayanan Publik; 3) Nilai tarif jasa pemrosesan sampah yang ditetapkan direalisasikan sesuai ketentuan peraturan perundang-undangan; dan 4) Pembayaran akan dilaksanakan oleh pihak kedua melalui Bendaharawan Umum Daerah Provinsi Sumatera Utara paling lambat 30 (tiga puluh) hari setelah tagihan bulan yang bersangkutan diterima oleh pihak pertama.

Terjadinya penumpukan sampah di beberapa kecamatan di kota Medan menyebabkan pengelolaan sampah di kota Medan menjadi tidak maksimal. Berarti pihak kedua yaitu pemerintah daerah telah melanggar Pasal 4 perjanjian kerjasama antara pemerintah provinsi Sumatera Utara dan pemerintah kota Medan mengenai hak dan kewajiban di dalam pengelolaan sampah.

\subsection{Masalah Penelitian}

Menurut uraian latar belakang diatas, maka dapat dirumuskan permasalahan sebagai berikut :

1. Bagaimana hukum perjanjian kerjasama antara Pemerintah Provinsi Sumatera Utara dengan Pemerintah Kota Medan Berdasarkan Peraturan Daerah Nomor 6 Tahun 2015 tentang Pengelolaan Persampahan?

2. Bagaimana hambatan yang ditemukan di dalam melaksanakan perjanjian kerjasama antara Pemerintah Provinsi Sumatera Utara dengan Pemerintah Kota Medan?

3. Bagaimana cara mengatasi hambatan yang ditemukan di dalam melaksanakan perjanjian kerjasama antara Pemerintah Provinsi Sumatera Utara dengan Pemerintah Kota Medan?

\subsection{Tujuan Penelitian}

\section{Tujuan Penelitian}

a. Untuk mengetahui hukum perjanjian kerjasama antara Pemerintah Provinsi 
Media Komunikasi dan Informasi Hukum dan Masyarakat

Sumatera Utara dengan Pemerintah Kota Medan Berdasarkan Peraturan

Daerah Nomor 6 Tahun 2015 tentang

Pengelolaan Persampahan.

b. Untuk mengetahui hambatan yang ditemukan di dalam melaksanakan perjanjian kerjasama antara Pemerintah Provinsi Sumatera Utara dengan Pemerintah Kota Medan Berdasarkan Peraturan Daerah Nomor 6 Tahun 2015 tentang Pengelolaan Persampahan.

c. Untuk mengetahui cara mengatasi hambatan yang ditemukan di dalam melaksanakan perjanjian kerjasama antara Pemerintah Provinsi Sumatera Utara dengan Pemerintah Kota Medan Berdasarkan Peraturan Daerah Nomor 6 Tahun 2015 tentang Pengelolaan Persampahan.

\section{Metode Penelitian}

Metode penelitian yang digunakan dalam penulisan hukum ini adalah penelitian hukum normatif yang berfokus pada asas - asas dengan merumuskan asas - asas hukum, baik dari data sosial maupun dari data hukum positif tertulis. Sedangkan jika dilihat dari sifatnya penelitian ini bersifat deskriptif. Penelitian deskriptif adalah memberikan data yang seteliti mungkin tentang manusia, keadaan atau gejala - gejala lainnya, dengan tujuan mempertegas hipotesa - hipotesa agar dapat membantu didalam memperkuat teori - teori lama atau dalam kerangka menyusun teori - teori baru.

\section{III.Hasil dan Pembahasan}

3.1. Hukum Perjanjian Kerja Sama Antara Pemerintah Provinsi Sumatera Utara Dengan Pemerintah Kota Medan Berdasarkan Peraturan Daerah Nomor 6
Tahun 2015 Tentang Pengelolaan

Persampahan

2008 tentang Pengelolaan Sampah mengamanatkan adanya kerjasama dan kemitraan antar pemerintah daerah, badan usaha dan pemberdayaan masyarakat dalam melakukan pengelolaan kebersihan terutama sampah. Pasal 26 ayat 1 menyebutkan : "Pemerintah daerah dapat melakukan kerjasama antar pemerintah daerah dalam melakukan pengelolaan sampah." Sementara pada pasal 27 ayat 1 menyebutkan : "Pemerintah daerah kabupaten/kota secara sendiri - sendiri atau bersama - sama dapat bermitra dengan badan usaha pengelolaan sampah dalam penyelenggaraan pengelolaan kebersihan terutama sampah".

Berdasarkan hasil penelitian, dapat dikatakan bahwa kebijakan kerjasama antara Pemerintah Provinsi Sumatera Utara dengan Pemerintah Kota Medan dalam pengelolaan persampahan ini memang diperlukan karena melihat adanya kesesuaian kebijakan yang dibuat dengan permasalahan yang ada. Bagaimanapun keadaannya, dengan adanya kerjasama ini sedikit banyak dapat membantu keterbatasan Pemerintah Kota Medan dalam menangani masalah pengelolaan sampah. di TPA. Melalui kerjasama antara Pemerintah Provinsi Sumatera Utara dengan Pemerintah Kota Medan tentunya hal tersebut dapat membantu mengurangi jumlah sampah. Secara tidak langsung pun, adanya kerjasama ini dapat memberikan manfaat warga Kota Medan secara keseluruhan baik dalam jangka pendek atau jangka panjang.

Pemerintah kota Medan dan Pemerintah Provinsi Sumatera Utara membuat perjanjian mengenai pengelolahan sampah 
Media Komunikasi dan Informasi Hukum dan Masyarakat

yang antara lain adalah pemerintah daerah membuat kebijakan dan strategi pengelolaan sampah, rencana induk pengelolaan sampah; dan studi kelaikan pengelolaan sampah. Di dalam perjanjian kerjasama antara pemerintah propinsi Sumatera Utara dengan pemerintah kota Medan, pemerintah daerah diperbolehkan untuk pengelolaan sampah ditangani oleh pemerintahan daerah sendiri.

\section{Berdasarkan Pasal 4 perjanjian} kerjasama antara pemerintah propinsi Sumatera Utara dan pemerintah kota Medan mengenai hak dan kewajiban pihak pertama (pemerintah propinsi Sumatera Utara) dan pihak kedua (pemerintah kota Medan) bahwa kewajiban pihak pertama adalah : memberikan pelayanan persampahan sesuai dengan syarat pelaksanaan yang diakui secara umum sesuai dengan standar dan pertanggungjawaban sesuai peraturan perundang - undangan yang berlaku untuk menjamin terlaksananya pelayanan pemrosesan sampah di TPA Sampah Regional; dan memberikan laporan kepada pihak kedua hasil pengelolaan sampah yang masuk ke TPA sampah regional secara berkala (bulanan, triwulan dan akhir tahun) atau sewaktu - waktu bila diperlukan oleh pihak kedua.

Kewajiban pihak kedua adalah : 1) Menjamin kebersihan, keamanan dan ketertiban (K3) terhadap pengiriman sampah dari Kabupaten/Kota sampai ke lokasi TPA Sampah Regional; 2) Menyediakan anggaran sebagai jasa pemrosesan sampah di TPA Sampah Regional yang akan ditetapkan berdasarkan kesepakatan para pihak dengan mempertimbangkan prinsip pemulihan biaya dan pelayanan Publik; 3) Nilai tarif jasa pemrosesan sampah yang ditetapkan direalisasikan sesuai ketentuan peraturan perundang - undangan; dan 4) Pembayaran akan dilaksanakan oleh pihak kedua melalui Bendaharawan Umum Daerah Provinsi Sumatera Utara paling lambat 30 (tiga puluh) hari setelah tagihan bulan yang bersangkutan diterima oleh pihak pertama.

Pemerintah Kota Medan dituntut untuk dapat mengelola sampah dengan baik dan kebersihan merupakan syarat bagi terwujudnya kesehatan dan sehat adalah salah satu faktor yang dapat memberikan kebahagiaan. Sebaliknya, kotor tidak hanya merusak keindahan tetapi juga dapat menyebabkan timbulnya berbagai penyakit dan sakit merupakan salah satu faktor yang mengakibatkan penderitaan. $\mathrm{Di}$ dalam pengelolaan persampahan pemerintah kota Medan bekerja sama dengan SKPD kota Medan yaitu Dinas Kebersihan.

\subsection{Hambatan yang Ditemukan Di Dalam} Melaksanakan Perjanjian Kerja Sama Antara Pemerintah Provinsi Sumatera Utara Dengan

\section{Pemerintah Kota Medan}

Di dalam penyelenggaran governance melibatkan tiga unsur utama (domain), yaitu state (negara atau pemerintahan), private sector (sektor swasta atau dunia usaha), dan society (masyarakat), yang saling berinteraksi dan menjalankan fungsinya masing-masing khususnya di dalam pengelolaan persampahan.

Kota Medan menghasilkan sampah sebanyak 2000 ton/hari sedangkan armda yang dimiliki oleh Pemerintah kota Medan melalui SKPD Dinas Kebersihan berjumlah 112 unit (83 unit truk kuning jenis Tiper dan 19 unit bak container jenis Anrol) dengan kondisi yang tidak memadai. Hal ini berdampak pada hasil yang tidak maksimal. Idealnya kota Medan membutuhkan 150 armada pengangkut sampah 
Media Komunikasi dan Informasi Hukum dan Masyarakat

di dalam mengangkut sampah sebanyak 2000 ton/hari ini.

Banyaknya jumlah sampah yang dihasilkan oleh kota Medan yang mencapai 2000 ton/hari menyebabkan SKPD kota Medan yaitu Dinas Kebersihan kota Medan mengalami kesulitan di dalam pengeloaan sampah. $\mathrm{Di}$ samping karena kurangnya armada pengangkut, kesadaran masyarakat kota Medan akan pentingnya di dalam menjaga kebersihan dan pengelolaan sampah juga masih kurang yang menyebabkan masalah pengelolaan sampah di kota Medan menjadi sulit untuk di tanggulangi. Walaupun, jumlah masyarakat yang membantu di dalam pengelolaan sampah ini makin berambah tetapi tidak sebanding dengan jumlah sampah yang dihasilkan pada setiap harinya.

Terjadinya penumpukan sampah di beberapa kecamatan di kota Medan menyebabkan pengelolaan sampah di kota Medan menjadi tidak maksimal. Berarti pihak kedua yaitu pemerintah daerah telah melanggar Pasal 4 perjanjian kerjasama antara Pemerintah Provinsi Sumatera Utara dan Pemerintah kota Medan mengenai hak dan kewajiban di dalam pengelolaan sampah.

3.2. Cara Mengatasi Hambatan yang Ditemukan Di Dalam Melaksanakan Perjanjian Kerja Sama Antara Pemerintah Provinsi Sumatera Utara Dengan Pemerintah Kota Medan

Dalam pengelolaan sampah, kota Medan memiliki peraturan khusus dalam pengelolaan sampah yaitu diatur dalam Peraturan Daerah Nomor 6 Tahun 2015 tentang Pengelolaan Sampah. Berdasarkan Pasal 1 Peraturan Daerah Nomor 6 Tahun 2015 tentang Pengelolaan Persampahan, bahwa: pengelolaan persampahan adalah kegiatan yang sistematis, menyeluruh dan berkesinambungan yang meliputi pengurangan dan penanganan sampah. Sampah sudah menjadi masalah bagi pelestarian lingkungan. Maka dari itu sudah menjadi tanggung jawab pemerintah daerah kota Medan dan kesadaran masyarakat untuk melestarikan lingkungan serta diperlukannya upaya pemecahan masalah sampah.

Aktor implementasi yang pertama dalam pelaksanaan perjanjian kerjasama antara Pemerintah Provinsi Sumatera Utara dan Pemerintah kota Medan dalam pengelolaan sampah adalah Dinas Kebersihan Kota Medan sebagai pelaksana teknis dalam pelaksanaan perjanjian kerja sama ini. Dinas Kebersihan Kota Medan ditunjuk oleh Pemerintah Kota Medan dalam pengelolaan sampah. Tupoksi yang dilimpahkan ke Dinas Kebersihan Kota Medan adalah pengawas teknis di lapangan yang mana menjalankan peran koordinasi atas kebutuhan teknis di lapangan serta kontrol lapangan.

Di dalam pelaksanaan perjanjian kerja sama pengelolaan sampah di Kota Medan ini, Dinas Kebersihan Kota Medan mengalami kesulitan di dalam mengelola sampah yang disebabkan karena kurangnya personil Dinas Kebersihan dan juga kurangnya jumlah sarana dan prasarana kebersihan. Terdapat beberapa cara mengatasi hambatan yang ditemukan di dalam melaksanakan kesepakatan dan perjanjian kerja sama antara Pemerintah Provinsi Sumatera Utara dengan Pemerintah Kota Medan berdasarkan Peraturan Daerah Nomor 6 Tahun 2015 Tentang Pengelolaan Persampahan yang antara lain adalah melakukan kerja sama dengan pihak swasta di dalam pengelolaan sampah, menambah jumlah personil, sarana prasarana Dinas Kebersihan 
Media Komunikasi dan Informasi Hukum dan Masyarakat

dan juga melakukan sosialisasi ke masyarakat mengenai pentingnya di dalam menjaga kebersihan dan pengelolaan sampah yang benar.

Pihak swasta merupakan salah satu komponen penyelenggara good governance. Pemerintah Kota Medan dapat menggandeng perusahaan (pihak swasta) sebagai mitra kerjasama dalam rangka mengelola sampah di TPA Kota Medan dalam bentuk pengolahan sampah menjadi pupuk organik melalui perjanjian kontrak kerjasama.

Peran dari pihak swasta ini dalam kerjasama antara Pemerintah Kota Medan sebagai mitra Pemerintah Kota Medan menjalankan peran sebagai pengelola persampahan di Kota Medan. Apabila kerja sama antara Pemerintah Kota Medan dengan pihak swasta dapat terjalin maka sampah dapat diambil oleh pihak swasta yang kemudian dimanfaatkan untuk diolah menjadi pupuk organik. Hal ini tentu dapat mengurangi persampahan yang ada di Kota Medan.

Peran masyarakat di dalam pengelolaan sampah juga sangat penting. Masyarakat merupakan salah satu aktor yang terlibat di dalam pelaksanaan sebuah kebijakan. Dalam melaksanakan sebuah kebijakan, peran masyarakat merupakan salah satu hal yang harus diperhatikan. Begitu pula dalam kebijakan kerjasama antara Pemerintah Provinsi Sumatera Utara dengan Pemerintah Kota Medan di dalam pengelolaan persampahan. Masyarakat memiliki peran yang cukup berpengaruh, yang mana dengan adanya keterlibatan masyarakat dapat mensukseskan kerjasama antara Pemerintah Provinsi Sumatera Utara dengan Pemerintah Kota Medan ini dalam mengelola sampah.
Berdasarkan hasil wawancara dengan Ibu Desmiati selaku Staf Sekretaris Pemerintah Kota Medan diketahui bahwa keterlibatan masyarakat dalam kebijakan kerjasama antara Pemerintah Provinsi Sumatera Utara dengan Pemerintah Kota Medan dalam pengelolaan sampah di TPA memang ada. Namun hanya sebagian kecil masyarakat yang ikut terlibat, khususnya hanya masyarakat yang ada di sekitar TPA. Masyarakat memiliki peran dalam membantu Dinas Kebersihan mengolah sampah melalu kontribusinya sebagai pekerja disana. Masyarakat Kota Medan secara umum tidak terlalu menunjukkan peran dalam berjalannya kerjasama tersebut. Peran masyarakat umum lebih kepada penanganan sampah sebelum sampah itu masuk ke TPA sehingga memudahkan keberjalanan tugas pengolahan di TPA.

Menurut Pasal 1 Peraturan Daerah Nomor 6 Tahun 2015 tentang Pengelolaan Persampahan, bahwa: "pengelolaan persampahan di selenggarakan berasaskan:
a. Asas tanggungjawab
b. Asas berkelanjutan
c. Asas manfaat
d. Asas keadilan
e. Asas kebersamaan
f. Asas keselamatan
g. Asas keamanan
h. Asas nilai ekonomi

Kebijakan kerjasama antara Pemerintah Provinsi Sumatera Utara dengan Pemerintah Kota Medan ini dilaksanakan oleh Dinas Kebersihan Kota Medan melalui UPTD TPA, didukung oleh Dinas Penanaman Modal dan Pelayanan Terpadu Satu Pintu Kota Medan, dan masyarakat sebagai subyek sekaligus obyek kebijakan. Dalam kebijakan ini semua aktor baik pemerintah, swasta dan masyarakat merupakan aktor implementasi penting karena masingmasing pihak memiliki tugas dan fungsi masing - 
Media Komunikasi dan Informasi Hukum dan Masyarakat

masing dimana tugas dan fungsi tersebut saling berkaitan antara yang satu dengan yang lain, sehingga dibutuhkan adanya kerjasama yang baik.

\subsection{KESIMPULAN DAN SARAN}

\section{A. Kesimpulan}

Berdasarkan hasil penelitian yang telah dilakukan, maka kesimpulan dalam penelitian ini adalah sebagai berikut:

1. Hukum perjanjian kerja sama antara Pemerintah Provinsi Sumatera Utara dengan Pemerintah Kota Medan berdasarkan Peraturan Daerah Nomor 6 Tahun 2015 Tentang Pengelolaan Persampahan adalah sebagai berikut pihak pertama (Pemerintah Provinsi Sumatera Utara) dan pihak kedua (Pemerintah Kota Medan) bahwa kewajiban pihak pertama adalah: memberikan pelayanan persampahan sesuai dengan syarat pelaksanaan yang diakui secara umum sesuai dengan standar dan pertanggungjawaban sesuai peraturan perundang -undangan yang berlaku untuk menjamin terlaksananya pelayanan pemrosesan sampah di TPA Sampah Regional; dan memberikan laporan kepada pihak kedua hasil pengelolaan sampah yang masuk ke TPA sampah regional secara berkala (bulanan, triwulan dan akhir tahun) atau sewaktu-waktu bila diperlukan oleh pihak kedua. Kewajiban pihak kedua adalah : 1) Menjamin kebersihan, keamanan dan ketertiban (K3) terhadap pengiriman sampah dari Kabupaten/Kota sampai ke lokasi TPA Sampah Regional; 2) Menyediakan anggaran sebagai jasa pemrosesan sampah di TPA Sampah Regional yang akan ditetapkan berdasarkan kesepakatan para pihak dengan mempertimbangkan prinsip pemulihan biaya dan pelayanan Publik; 3) Nilai tarif jasa pemrosesan sampah yang ditetapkan direalisasikan sesuai ketentuan peraturan perundang - undangan; dan 4) Pembayaran akan dilaksanakan oleh pihak kedua melalui Bendaharawan Umum Daerah Provinsi Sumatera Utara paling lambat 30 (tiga puluh) hari setelah tagihan bulan yang bersangkutan diterima oleh pihak pertama.

2. Hambatan yang ditemukan di dalam melaksanakan perjanjian kerja sama antara Pemerintah Provinsi Sumatera Utara dengan Pemerintah Kota Medan berdasarkan Peraturan Daerah Nomor 6 Tahun 2015 Tentang Pengelolaan Persampahan adalah jumlah dan kondisi yang tidak memadai pada armada yang dimiliki oleh Pemerintah kota Medan melalui SKPD Dinas kebersihan berjumlah 112 unit (83 unit truk kuning jenis Tiper dan 19 unit bak container jenis Anrol) tidak sebanding dengan volume sampah yang dihasilkan perharinya, dan kurangnya personil Dinas Kebersihan.

3. Cara mengatasi hambatan yang ditemukan di dalam melaksanakan perjanjian kerja sama antara Pemerintah Provinsi Sumatera Utara dengan Pemerintah Kota Medan berdasarkan Peraturan Daerah Nomor 6 Tahun 2015 Tentang Pengelolaan Persampahan adalah dengan menggandeng pihak ketiga yaitu pihak swasta sebagai mitra kerjasama dalam rangka mengelola sampah di TPA Kota Medan dalam bentuk pengolahan sampah menjadi pupuk organik melalui perjanjian kontrak kerjasama dan juga melakukan sosialisasi kepada masyarakat bagaimana 
Media Komunikasi dan Informasi Hukum dan Masyarakat

tentang hidup sehat dan bersih, sebab sampah bisa menyebabkan limbah dan berakibat pada lingkungan sekitar maupun berakibat pada penyakit yang di bawa oleh bakteri mau pun virus.

\section{B. Saran}

Berdasarkan kesimpulan penelitian yang telah dipaparkan, maka saran dalam penelitian ini adalah sebagai beikut:

1. Sebaiknya pihak Pemerintah Kota Medan melakukan/menggandeng pihak ketiga yaitu pihak swasta sebagai mitra kerjasama dalam rangka mengelola sampah di TPA Kota Medan dalam bentuk pengolahan sampah menjadi pupuk organik melalui perjanjian kontrak kerjasama.

2. Sebaiknya pihak Pemerintah Kota Medan melakukan sosialisasi kepada masyarakat terkait dengan Peraturan Daerah Nomor 6 Tahun 2015 Tentang Pengelolaan Persampahan.

\section{Daftar Bacaan}

\section{A. Buku}

Amiruddin, 2012, Pengantar Metode Penelitian Hukum, PT Raja Grafindo, Jakarta.

Badrulzaman, Mariam Darus, 2001, Kompilasi Hukum Perdata, PT. Citra Aditya Bakti, Bandung.

Budiono, Herilien, 2009, Ajaran Umum Hukum Perjanjian dan Penerapannya di Bidang Kenotariatan, Citra Aditya Bakti, Bandung.

HR, Ridwan, 2011, Hukum Administrasi Negara, PT. Grafindo Persada, Jakarta,

Kadir, Muhammad Abdul, 1990, Hukum Perjanjian, Citra Aditya Bakti, Bandung.

Kelsen, Hans, 2011, Teori Umum Tentang Hukum dan Negara, terjemahan Muttaqien, Raisul, Nusa Media, Bandung.

Komariah, 2008, Hukum Perdata, UMM Press, Malang.

Mahendra, Yusril Ihza, 2010, Dinamika Tata Negara Indonesia, Gema Insani Pers, Jakarta.

Manan, Bagir, 2006, Lembaga Kepresidenan, FHUI, Jakarta.

Mertokusumo, RM. Sudikno, 1995, Mengenal Hukum Suatu Pengantar, Liberty, Yogyakarta.

Nasional, Departemen Pendidikan, 2007, Kamus Besar Bahasa Indonesia, Balai Pustaka, Jakarta.

Raharjo, Satjipto, 2004, Masalah Penegakan Hukum : Suatu Tinjauan Sosiologis, Sinar Baru, Bandung.

Rahmadi, Takdir, 2014, Hukum Lingkungan di Indonesia, Rajawali Pers, Jakarta. 
Media Komunikasi dan Informasi Hukum dan Masyarakat

Riawan, 2009, Hukum Pemerintahan Daerah, Citra Aditya Bakti, Bandung.

Setiawan, R, 1999, Pokok-Pokok Hukum Perikatan, Putra A.Bardin, Bandung.

Sunarno, Siswanto, 2008, Hukum Pemerintahan Daerah di Indonesia, Sinar Grafika, Jakarta.

Soekanto, Soerjono, 2007, Faktor-faktor Yang Mempengaruhi Penegakan Hukum. Raja Grafindo Persada, Jakarta.

Subekti, R., 2010, Hukum Perjanjian, Intermasa, Jakarta.

Supriadi, 2005, Hukum Lingkungan di Indonesia, Sinar Grafika, Jakarta.

Unsfunan, Johanes, 2002, Perbuatan yang dapat Digugat, Jambatan, Jakarta.

\section{B. Peraturan Perundang-Undangan}

Undang-Undang Dasar 1945.

Undang-Undang Nomor 23 Tahun 1997 Tentang Pengelolaan Lingkungan Hidup.

Undang-Undang Nomor 40 Tahun 2007 tentang Perseroan Terbatas

Undang-Undang Nomor 18 Tahun 2008 tentang Pengelolaan Sampah

Peraturan Daerah Kota Medan Nomor 6 Tahun 2015 Tentang Pengelolaan Persampahan.

\section{Jurnal}

Bickel, Balthasar, 2007, Two Ways of Suspending Object Agreement in Puma between Incorporation and Optional Agreement, Journal of Himalayan, University of California, Vol 7 No. 1.

Hutler, Brian Jeffrey, 2018, Cooperation, Religious Freedom, and the Liberal State, Journal of UCLA and Dissertations, University of California,Vol 1 No. 1.
Mardalena Hanifah, 2014, Perjanjian Sewa Beli Menurut Hukum Perdata,, Jurnal IImu Hukum. Fakultas Hukum Universitas Andalas, Vol. 21 No. 1.

Marvita Langi, 2016, Akibat Hukum Terjadinya Wanprestasi Dalam Perjanjian Jual Beli, Jurnal Lex Privatum, Vol. IV/No. 3/Mar/2016.

Nopyandri, 2011, Penerapan Prinsip Good Environmental Governance dalam Perda Kabupaten Sleman Provinsi Daerah Istimewa Yogyakarta, Jurnal IImu Hukum, Vol. 2 No. 1.

Perdana, Afrilian, Dahlan dan Mahfud, 2014, Penyelesaian Wanprestasi Dalam Perjanjian Jual Beli Melalui Media Elektronik, Jurnal IImu Hukum Pascasarjana Universitas Syiah Kuala, Vol 2. No.1.

Prayogo, Sedyo, 2016, Penerapan BatasBatas Wanprestasi Dan Perbuatan Melawan Hukum Dalam Perjanjian, Jurnal Pembaharuan Hukum, Volume III No. 2.

Schoenvogel, Sally E., 2013, Advanced Media Agreement May Violate Antitrust Law, Journal of UCLA Entertainment Law, University of California, Vol 20 No. 2.

\section{Website}

http://www.kamus hukum.html

http://www.wikipedia.com.html 